\title{
Needs Analysis Survey on Business English Teaching to EFL Learners
}

Shirin Shafiei Ebrahimi*

Lecturer in English, Nizwa College of Technology, Sultanate of Oman; shirin.shafiei@gmail.com

\begin{abstract}
This study aims to showcase a new approach to teach business English to EFL learners. There are several questionnaires that are suggested to be used before and during business English teaching. The questionnaires will provide the teachers with valuable data about the level and expectations of the students so that they would be able to choose the most suitable material to teach them. An interview was also conducted with the owner and the manager of the company separately in order to detect their priorities and expectations from the course. The result showed that following the needs analysis suggested in this study suits EFL students, and it is recommended that other teachers do so for their business English classes.
\end{abstract}

Keywords: Business English Teaching and EFL, Needs Analysis

\section{Introduction}

Effective business English teaching has long occupied the minds of English teachers. Because of the special needs of business people who are mostly in a rush to learn the language quickly, this study initiated a perspective to business English teaching to these groups of professionals through some needs analysis before and during the main course ${ }^{5}$. In order to collect the data, the two following methods were chosen: Mailing questionnaire and Mailing Interview. The source of information was extracted from the owner, trade manager and staff members of the import section of a middle-sized company. Both questionnaire and interview questions are available in the Appendix section at the end of the study. The result shows that the recommended approach in teaching business English works well to the learners and it is safe if other teachers can follow the same approach.

\section{Target Situation Analysis}

For this study, a medium-size business company was selected in 2019. A total number of six staff from the commercial section of the company showed interest in joining the English classes. All of them were Iranians, including two females and four males. Five of them were in the age range of 28-38 and one of them was in the age range of 39-49. Two of them had MA degrees and the other four had a BA degree in Business Management, Economic Management, English Translation and MBA. In total, 4 of them passed ESP courses before the class and 2 of them did not.

Table 1. Students' bio-data

\begin{tabular}{|c|c|c|c|c|c|}
\hline Student number & Gender & Age Range & $\begin{array}{c}\text { University } \\
\text { Degree }\end{array}$ & Major & $\begin{array}{c}\text { No. of EAP courses which } \\
\text { has been passed }\end{array}$ \\
\hline Student 1 & Female & $28-38$ & MA & Economic Management & 2 \\
Student 2 & Male & $28-38$ & BA & Business Management & 2 \\
Student 3 & Male & $28-38$ & BA & Business Management & 3 \\
Student 4 & Female & $28-38$ & BA & English Language & 0 \\
Student 5 & Male & $28-38$ & MA & MBA & 3 \\
Student 6 & Male & $39-49$ & BA & Teaching English & 0 \\
\hline
\end{tabular}

*Author for correspondence 
According to Table 2, General English Proficiency of the learners is between Intermediate and Upper Intermediate levels, so there is no need to have any general

Table 2. Students' level of proficiency

\begin{tabular}{|c|c|c|c|c|c|}
\hline Student number & Speaking & Reading & Writing & Listening & Grammar \\
\hline Student 1 & Intermediate & Upper Intermediate & Intermediate & Intermediate & Intermediate \\
Student 2 & Upper Intermediate & Intermediate & Intermediate & Beginner & Beginner \\
Student 3 & Intermediate & Intermediate & Intermediate & Upper Intermediate & Intermediate \\
Student 4 & Advance & Advance & Advance & Advance & Advance \\
Student 5 & Advance & Upper Intermediate & Advance & Advance & Upper Intermediate \\
Student 6 & Beginner & Intermediate & Intermediate & Intermediate & Intermediate \\
\hline
\end{tabular}

The learners' communicative activities used in this course were answering the phone, chatting online, sending and replying to E-mails, asking for new products and catalog, writing business contracts, asking for price lists. Most of them have one year or less than one year of experience in these activities and also there is a new staff. Based on their answers all of them have studied general English at some private schools.

\section{Views on Learning English}

\subsection{Staff's Motivation for EOP Course}

Staff wished to communicate in English with International companies to improve their speaking, writing and listening. Staff preferred learning styles of Group work, Role play, Presentations and lectures and Task-based workshop.

\subsection{Company Owner's Views}

There were four interview questions for the owner about the below topics which he replied accordingly (see Appendix A):

\subsubsection{Vision and Mission of the Company}

This company imports some materials from different countries all over the world.

\subsubsection{Aims of EOP Classes}

Due to the high rate of imports from China and the Western countries, it is essential for us to increase the abilities of the staff to be able to communicate, contact and have a good relationship with all companies and factories which we are connected.
English courses as a kind of pre-requisite for EOP (English for Occupational English) course.

\subsubsection{Equipment and Facilities}

Some equipment and facilities such as a video projector, conference room and audio and video facilities are available in order to have a good EOP class.

\subsubsection{Value System}

In preparation for a learner to be an effective participant in their professional community, it is essential that the training covers the value system and work culture of that target community. As Donaldson and Dunfee ${ }^{2}$ explained: "Economic systems are products of artifice, not nature and their structures can and do vary immensely." Artifacts are such systems that include the laws, practices and value systems that inform economic practices. These are individuals who create and make them what they are. Different individuals may have chosen to make them differently. There is no international value system in the world of business and the value system of each type of business changes due to the type of the target community that works in it.

The standards of performance, which considered useful in this particular company, are listed as:

Honesty, cooperation, teamwork among all members and divisions, coordination between departments (e.g. import and commercial sections), discipline in company policy, rules, systems and standards, freedom for employees to make suggestions, develop plans and carry out actions.

\subsection{Trade Manager's Views}

Totally 11 questions were asked from the trade manager which are replied as below (see Appendix B):

\subsubsection{Trade Manager Expectation}

The trade manager wants his staff in the import section of the company to be able to speak and write in English 
very well for the smooth delivery of the import process. The import procedure is first to ask for new products from different companies and ask them to send some samples with the price list. After checking the quality, a contract is made and by following the commercial procedures (opening letter of credit, goods transportation, customs declaration), the products will be available at the company. Therefore, writing and speaking are two primary skills that staff deals with according to their job in import section.

\subsubsection{Weak Points and Difficulties of Staff}

Staff is not updated regarding the use of commercial terms. They need to know more about new business vocabularies, abbreviations and lecture presentations. They need to talk more fluently and also improve their listening skills. The company should be updated using new technical terms to have the ability to compete with the global market. The staff members are trade experts, trade managers, technical managers, trade staff, bankers, customs, staff and marketers. Besides, the best time for holding the class is after office hours so that they are free to join.

\subsubsection{Communicative Activities in the Target Community}

Communicative activities involved in the import section are phone calls, sending and receiving emails, chatting online, using some software, writing contracts.

\subsubsection{Required Knowledge and Skills}

According to Dudley-Evans ${ }^{3}$, English for Specific Purposes (ESP) courses should be offered at intermediate or advanced levels by use of authentic learning material. Based on the company target situation analysis the proficiency level of all staff members are intermediate or upper-intermediate, so there is no need to pass general English language skills; therefore, learners need to learn speaking and writing skills in specific areas as follows:

\subsubsection{Writing}

Contract writing, business E-mail writing, enquiries, complaining.

\subsubsection{Speaking}

Speaking through phone, chatting online, lecture, presentation.

Based on so many studies ${ }^{6}$, in order to speak very well, learners need to have a good listening comprehension and pronunciation skills and also in order to write very well learners need to have a good reading comprehension and excellent range of vocabulary knowledge. The specific areas of these two skills are:

\subsubsection{Listening}

Listen to the customers, technical experts and marketers; also presentations and lectures through phone or face to face interactions.

\subsubsection{Reading}

Reading business E-mails, reading books, manual instructions and specifications, reading contracts, reading proforma invoice, import regulations and laws, incoterms, commercial vocabulary, business terms.

\subsubsection{Teaching and Learning Environment}

According to the needs analysis, $80 \%$ of the staff in the import section of this company have their oral and written communications with international companies in English, so English has the central role in this section. The ESP course tries to relearn business English in oral and written form and make the staff updated with new business vocabularies and commercial terms. ESP courses were held on-site and part-time two days a week in the afternoons for seven weeks for a total 30 hours.

The facilities available were video projector, internet connection, conference room, portable chair, private computers, last version of Skype software, last version of Microsoft Office, Outlook and a whiteboard.

\section{Methodology}

According to the syllabus, the methodology was based on CLT (Communicative Language Teaching Approach) and TBL (Task-based Learning). Speaking was taught in the form of role-playing in pair work form and writing in task format and deductive form. As learners are busy with their jobs, they cannot focus on homework and so the methodology should be student-based, and also students talking time should be increased. All classes are held in the conference room.

This course was a 30-hour course for staff in the commercial section of a factory to improve their abilities in their jobs dealing with English. It was recommended to give promotion from the manager for top students as an incentive. Those learners who got good marks had promotion and a raise in their salary. 


\subsection{Materials of the Syllabus}

\subsubsection{Books}

There are many books related to business English, "Oxford Handbook of Commercial Correspondence" is a good source for writing tasks. Besides, there are more books listed below:

- In Company (second edition) published by Macmillan and authors are Mark Powell, Simon Clarke and Pete Sharma. This book has topic-based content, active skills and real-world tasks.

- Meetings in English, published by Macmillan and the author is Bryan Stephens. This book deals not only with the communication skills necessary for a wide range of meeting context but also with the networking skills required to build an effective relationship.

\subsubsection{Websites}

There are some websites which are good sources in English business:

- Conversations at work: Talk in the c work: www.eslgold. com/business/

- A British magazine with a very global reach: www.economisit.com

- Bloomberg offers a lot of technical information on the business and financial world: www.bloomberg.com

- Google News in English is also helpful. Learners can search for the name of their country and find so many business articles

- Slate: An exclusively online magazine with good articles and extensive links

\subsubsection{Business News}

Some useful business news to be used in the class is:

- Wall street journal provides the latest news in the business world: www.online.wsj.com

- Business week online is an online magazine with news and articles: www.businessweek.com

- BBC business English (a business section of the BBC news).

- American Business English (Karen Hulene Bartlle) published by Michigan University Press.

The only stakeholders in a business company are the president of the company or board of directors. For the president and board of directors, having a good relationship and communication in English without any problem, in reality, is essential. Therefore, any material in this syllabus should be able to be applied later and should be understood by the others in the business world. Communication in English is essential, while the accuracy in grammar is not that much important.

\subsection{Content}

Principles in conceptualizing content.

\subsubsection{Students will Learn in this Course}

Through this course, students (employees) will learn to handle their jobs and duties. Learners, as commercial traders should know how to communicate in English.

\subsubsection{Options to Learn}

Learners study every subject that is familiar to their jobs and duties, which is related to business words, expressions and terms, business talks (telephoning and meeting) and business writing (correspondence).

\subsubsection{Resources and Constraints}

There are three significant resources:

Written resources: Books, magazines, newspapers, handouts, dictionary of business terms and idioms; Web resources: E-magazines, e-news websites, educational websites and articles related to business; Audio and video resources: CDs related to written resources, podcasts related to web resources and business speeches and news plus some videos related to meetings and presentations.

Guides and instructions related to software (Outlook, Skype and Trade Managers) are also essential to be reviewed for further understanding.

\subsubsection{Options Relationship}

The options are related in a way that all of them contribute to the aim of this syllabus, which is enabling students to communicate fluently orally and in written form. For this reason, different chapters of the syllabus introduced new words and functions related to the business context.

\subsubsection{Principle of Organizing Content}

Focus on language: It is a topical syllabus based on integrated skills.

Less Focus on learning and the learner: There is less focus on learning and the learner and it is just for interpersonal skills, which can be seen in group works and role-plays.

Less Focus on social context: There is less focus on socio-cultural skills and sociolinguistic skills. 


\subsection{Goals and Objectives}

To prepare commercial staff to communicate in the English language for business purposes. Also, develop employees' linguistic and socio-linguistic ability and communicative competence in predictable and specific English business context.

Goal 1: Students will be able to make use of the skills of listening and speaking for business communications, business meetings, and business presentations in the specified topics.

Objectives: Students will be able to:

- Have a good listening comprehension and understand business terms and expressions and to talk face to face in meetings and presentations and being able to talk on the phone;

- Talk politely and formally;

- Agree and disagree and ask for clarification and make a request, offer, and complain.

Goal 2: Students will be able to develop the skills of reading and writing for written communication, corresponding, getting information (business expressions and terms) in topics' areas.

Objectives: Students will be able to:

- Write reports and different form of business letters such as a letter of complaint and inquiry;

- Read a letter of credit and get familiar with business expressions and abbreviations;

- Read and write business e-mails;

- Read business articles, magazines and news to be updated and aware of business around the world.

Goal 3: Students will develop skills that enable them to communicate via different software in business English.

Objectives: Students will be able to:

- Do their jobs with Outlook as e-mail software, Skype as a communication software and Trade Manager as marketing and chatting software.

\subsection{Organization of the Units}

The unit organization is based on a cycle in which it starts with listening and then reading. Afterwards, it is speaking in the form of role-playing and discussion. Next is writing, and in the end, it is a case study or workplace skills.

For instance, first, learners listen to the podcast with this title: "Outlook, share point and business technology podcast" from www.thepodlounge.com.au. And then for week five, the topic is technology in business; students read an article with the title "barriers to using Skype for business fall away" by Tim Greene from www.infoworld.com. For speaking, learners try to have conversations via Skype/ Pal talk software. In the writing part, students try to write an e-mail using Outlook. This e-mail can be a summary of the reading or listening part. In the end, for workplace skills, learners should write online about one of the software which they have learned before and e-mail it to each other for peer corrections and finally give the report to the teacher. The sequence is from simple topics to difficult ones and also from more controlled activities to more open-ended ones.

\section{Need Analysis}

Using a questionnaire (initial and final):

Initial: Possible goals and objectives from the learners' perspective.

Final: Getting feedback from students whether the syllabus meets their expectations or not.

Interview: Asking some questions from stakeholders about their targets, needs and goals. Also, ask questions from some of the students to find out their ideas about this program.

In-class discussions: To find weak points in different skills and find the most exciting topics from learners' points of view.

The role of needs assessment is the development of our syllabus.

Questions that need assessment are:

1. Are topics related to your field of business?

2. Does the level of your language proficiency go well with this program?

3. Has your level of intercultural competence improved during this course?

4. Are you interested in the topics?

5. Are your learning preferences prioritized?

6. Is the part "using technology in business" contributed to a better understanding of the course?

7. Does this course meet your expectations?

8. Do communicative skills and tasks prepare you for real situations? 
9. Can you write business letters without difficulty?

10. Do you have any problem reading business texts? (Newspapers, magazines, and articles)

\section{Assessment Plan}

\subsection{Assessing Proficiency}

In the beginning, we have placement tests to be sure about learners' needs. In the end, we have interviews for assessing proficiency. It is possible to assess the syllabus following BEC (Business English Course) Cambridge University sample exams, as a good indicator of achievement.

\subsection{Diagnosing Ability/Needs}

It was designed to find out what students can and cannot do concerning a task, skill or content area. This process usually deals with what the students know how to do (abilities) and what they do not know how to do (needs). For example, when students are required to write a letter of credit, they can write the receiver and sender address (abilities). On the other hand, they cannot write an introduction and the body of the letter (needs).

\subsection{Assessing Progress}

Every two weeks, there was one assessment, so we had four assessments during the course. The assessment was held with the presence of the owner. It is due to the engagement of learners. This assessment also could help us to focus on learners' success in what they had learned.

\subsection{Assessing Achievement}

It was not expected to give grades to students, but assessing achievement results were divided into three parts: Weak, pass, excellent. Those students who got excellent would be introduced to the boss for a promotion. The basis for the final assessment was Case studies, workplace skills, role plays, and group works.

\section{Evaluating the Course}

The evaluation was divided into three parts: Evaluation of the teacher, which was in the form of implementations issue. Evaluation of students with questionnaires and evaluation of stakeholders with interviews. The final question of evaluation was if students achieve the expected goal of this course.

\section{Syllabus Design}

According to target situation analysis and based on the characteristics of different types of syllabuses there is more than one type of syllabus that suits EOP students, such as skill-based syllabus, functional and also topical syllabus. Among them, the best choice for this project was mixed of situational syllabus (which is the most flexible one and also based on this fact that EOP is more concerned with the content and format) and skill-based syllabus. According to TSA, students needed speaking and writing more than listening and reading, but as in our methodology, we used an integrated approach meaning that all skills were used together.

\subsection{Syllabus Design Supported Theories}

As Dudley-Evans and John ${ }^{4}$ stated that the teaching process of any language for functional purposes should take as a starting point the analysis of four traditional skills within an appropriate context that is as far as possible the conditions given in the workplace. Moreover, they subscribe to the idea that a practical syllabus must attempt to overcome the deficiencies of the educational system under which they are operating.

\subsection{Situational Topical Syllabus}

This type of syllabus is based on communication situations and topics that learners need to discuss and it is near to the functional notional syllabus. It highly motivates learners, because they feel that the syllabus meets their everyday communication needs. Due to the situational, topical syllabus limitations (it is just limited in a specific situation or topic) with combining skill-based syllabus, a more reliable and effective syllabus could be suggested.

\subsection{Course Outline}

Weekly Schedule

Week 1: Introduction, assessment and consultation.

Week 2: Me and My office.

Week 3: Meeting and presentations.

Week 4: Telephoning and negotiations in business.

Week 5: Business (Export/import) terms and idioms.

Week 6: Marketing.

Week 7: Social and cultural and ethical aspects of business.

Week 8: Technology in business.

Learning Hours: 30 hours. 


\subsection{Syllabus Mapping}

According to the weekly outline, the first week was an introduction to the course and the teacher got to know learners, consult with them and made sure that the target situation analysis assesses correctly through the feedback of learners. In the second week, office communications were discussed and learners listened to the non-authentic listening related to job titles. Furthermore, learners described their jobs. In the third week, learners listened to an authentic listening about a famous perfume, 'Van essence' and wrote a report about it as well as the board of directors meeting and also presented company's new product and wrote an outline for a presentation before the lecture. The fourth week was related to telephoning and negotiating. Learners listened to an extract of negotiation from virtual chat rooms' authentic recorded files. They had a role-play conversation about a new sales contract.
One of them had to be a commercial expert and the other had to have the customer role. They had a reading passage with the following title: Important tips in business negotiations. In the fifth week, learners probed samples of contract and invoice and they were asked to write an e-mail for another company and ask for the price list and catalog and write a sales contract. The sixth week was related to value system. They discussed customers' rights. They also had a reading about the role of ethical issues in business. Finally, they wrote a reply to a customer's complaint letter. In week seven, learners learned about communicating with webbased applications in business. A podcast about outlook, share point and business technology was introduced. They learned how to speak with palk talk, Skype, trade manager (alibaba.com), forum and chat rooms. They went to alibaba. com, ebay.com and wrote a report about different parts and benefits of these websites. In the last week, they listened to a

Table 3. Syllabus mapping

\begin{tabular}{|c|c|c|c|c|c|}
\hline \multirow[b]{2}{*}{ Topic/Skills } & \multicolumn{2}{|c|}{ Communication skills } & \multirow{2}{*}{$\begin{array}{c}\text { Reading Skills } \\
\text { (Reading as a } \\
\text { process) } \\
\end{array}$} & \multirow[b]{2}{*}{ Correspondence skills } & \multirow{2}{*}{$\begin{array}{l}\text { Workplace skills/ } \\
\text { Case study }\end{array}$} \\
\hline & $\begin{array}{l}\text { Listening and } \\
\text { pronunciation }\end{array}$ & Speaking & & & \\
\hline \multicolumn{6}{|l|}{$\begin{array}{l}\text { Week 1: } \\
\text { Introduction, } \\
\text { Assessment and } \\
\text { consultation }\end{array}$} \\
\hline $\begin{array}{l}\text { Week 2: } \\
\text { Me and My office }\end{array}$ & $\begin{array}{c}\text { Job titles and } \\
\text { different } \\
\text { Commercial sections }\end{array}$ & $\begin{array}{c}\text { Describing your job. } \\
\text { Describing your } \\
\text { company }\end{array}$ & My office work & $\begin{array}{c}\text { Writing a letter to a } \\
\text { colleague about your } \\
\text { tasks }\end{array}$ & $\begin{array}{l}\text { Describing your } \\
\text { colleagues' tasks }\end{array}$ \\
\hline $\begin{array}{l}\text { Week 3: } \\
\text { Meeting and } \\
\text { presentations }\end{array}$ & $\begin{array}{c}\text { Samsung's board } \\
\text { of directors } \\
\text { Meeting(Authentic) }\end{array}$ & $\begin{array}{l}\text { Present factory's new } \\
\text { product }\end{array}$ & $\begin{array}{c}\text { Tom's presentation } \\
\text { in an international } \\
\text { meeting }\end{array}$ & $\begin{array}{l}\text { How to write } \\
\text { an outline for } \\
\text { presentation }\end{array}$ & $\begin{array}{l}\text { Write a report on } \\
\text { Samsung's board of } \\
\text { directors meeting. }\end{array}$ \\
\hline $\begin{array}{l}\text { Week 4: } \\
\text { Telephoning and } \\
\text { negotiations in } \\
\text { business }\end{array}$ & $\begin{array}{l}\text { Negotiations in } \\
\text { virtual chat rooms }\end{array}$ & $\begin{array}{c}\text { Role play, conversation } \\
\text { about a new sales } \\
\text { contract }\end{array}$ & $\begin{array}{l}\text { Important tips } \\
\text { in business } \\
\text { negotiations }\end{array}$ & $\begin{array}{l}\text { Write to ask different } \\
\text { payment terms in a } \\
\text { sales contract }\end{array}$ & $\begin{array}{l}\text { Negotiate with your } \\
\text { boss about delivery } \\
\text { terms in a sales } \\
\text { contract }\end{array}$ \\
\hline $\begin{array}{l}\text { Week 5: } \\
\text { Business (Export/ } \\
\text { import) terms and } \\
\text { idioms }\end{array}$ & - & $\begin{array}{l}\text { A presentation about } \\
\text { annual export and } \\
\text { import }\end{array}$ & $\begin{array}{l}\text { how is it possible } \\
\text { to import } \\
\text { standard goods } \\
\text { with high quality }\end{array}$ & $\begin{array}{l}\text { Contract sample } \\
\text { writing }\end{array}$ & $\begin{array}{l}\text { Writing an email for } \\
\text { another company } \\
\text { and asking for a } \\
\text { price list and catalog }\end{array}$ \\
\hline $\begin{array}{l}\text { Week 6: } \\
\text { Marketing }\end{array}$ & $\begin{array}{l}\text { A radio program } \\
\text { about different ways } \\
\text { of marketing }\end{array}$ & $\begin{array}{l}\text { Discussing marketing } \\
\text { strategies - e.g., for } \\
\text { famous brands }\end{array}$ & $\begin{array}{c}\text { Newspaper: article } \\
\text { about Toyota`s } \\
\text { strategies in } \\
\text { marketing }\end{array}$ & $\begin{array}{l}\text { Write an e-mail to fix } \\
\text { new prices for main } \\
\text { costumers }\end{array}$ & $\begin{array}{l}\text { Design a marketing } \\
\text { plan for your factory }\end{array}$ \\
\hline $\begin{array}{l}\text { Week 7: } \\
\text { Social and Cultural } \\
\text { and ethical aspects } \\
\text { of business }\end{array}$ & $\begin{array}{c}\text { Ford managers } \\
\text { have meetings with } \\
\text { customers }\end{array}$ & $\begin{array}{l}\text { Discussing customer's } \\
\text { rights }\end{array}$ & $\begin{array}{c}\text { Role of ethical } \\
\text { issues in business }\end{array}$ & $\begin{array}{l}\text { Write a reply to a } \\
\text { complaint letter which } \\
\text { is sent by a customer }\end{array}$ & $\begin{array}{c}\text { Write a report } \\
\text { about your factory's } \\
\text { policies toward } \\
\text { customers. }\end{array}$ \\
\hline $\begin{array}{l}\text { Week 8: } \\
\text { Technology in } \\
\text { business }\end{array}$ & $\begin{array}{c}\text { Outlook, share } \\
\text { point, and business } \\
\text { technology (podcast) }\end{array}$ & $\begin{array}{c}\text { Palk talks /Skype trade } \\
\text { manager / forums and } \\
\text { chat rooms } \\
\text { Conversations }\end{array}$ & $\begin{array}{l}\text { barriers to using } \\
\text { Skype for business } \\
\text { fall away }\end{array}$ & $\begin{array}{c}\text { write an e-mail using } \\
\text { outlook } \\
\text { about three advantages } \\
\text { of technology in } \\
\text { business }\end{array}$ & $\begin{array}{l}\text { Go to alibaba.com } \\
\text { ebay.com } \\
\text { And write a report } \\
\text { about these websites }\end{array}$ \\
\hline
\end{tabular}


conversation between a banker and commercial staff and also had a role play in the costumes and banking context. They had a reading about customs and banking regulations, and terms and they revised a Letter of Complaint (LC) and postponed the time of the LC to another time and wrote it in the form of an email.

\section{Implementations}

The time of the classes is essential. In factories, stakeholders hold the classes at lunchtimes or break times, which is not efficient. It is an issue to find the best time for employees because they are working during the day and at lunch or break times they need to relax. Afternoon classes are not convenient because employees are tired. Accordingly, there are two ways to solve this problem. The first can be finding time after a break or at noon or time in the morning for the classes. It is better to have classes in the morning when students are fresh to learn. However, finding free time, in this case, is too difficult. The next solution can be finding a time that employees and managers are all free, which is also a tough job.

Mixed ability students may cause some problems. Moreover, they are from different age groups and some of them are good at writing, not speaking due to their positions and responsibilities. There may be some employees with good writing skills who send and receive e-mails frequently and some employees who work as marketers, so they are good in speaking; therefore, it is essential to start from the basic needs and make the units more challenging gradually and start from known to unknown subjects.

Some problems might happen due to wrong ideas, and actions arising among business persons, especially in their pronunciations (for example the pronunciation of a business word in a dictionary and something they think and pronounce in reality is different.

This course did not cover top students with an excellent command of English as well as weak students. Those who have good competence in English communication do not need this course and those who are weak in the English language cannot fit themselves in this program as their competencies of English are too low.

Most of the time, there is a gap between theory and practice. Therefore, it is recommended to choose a teacher who has some practical knowledge besides the theoretical knowledge, and it's better that the teacher is chosen from staff. However, it is not always possible to find a good teacher with a high level of fluency among staff.

\section{Conclusion}

Based on the above-mentioned implications, it is concluded that business English can be taught to the staff of different companies based on the needs of the owners, managers and the staff. They can learn the material which is most relevant to their positions and everyday job in a better sense if they practice it day today. As a result, they are either able to learn better from their colleagues rather than from an English teacher with no idea about the business context or the teachers have to equip themselves with enough content knowledge to be able to teach effectively and adequately. The teacher can choose the material from basic to advanced levels of difficulty for the learners to be more understandable. It is also needless to mention the factor of time that has to suit the learners. Therefore, the timing has to be discussed and chosen based on their work time and free time.

\section{About the Author}

Dr. Shirin Shafiei Ebrahimi is an English lecturer at Nizwa College of Technology, Sultanate of Oman. She is interested in teaching English for Specific Purposes (ESP) and has taught English to students of various disciplines with different backgrounds for many years.

\section{Acknowledgment}

The author would like to highly appreciate Mr. Justin James, E-learning Coordinator and Lecturer at Nizwa College of Technology and Dr. A. Vanitha, Assistant Professor of English at Vellalar College for Women (Autonomous), India, for their invaluable supports for publishing this work.

\section{Reference}

1. Brown G. Teaching listening comprehension. Listening to Spoken English. Routledge. 2017. p. 158-86. https://doi. org/10.4324/9781315538518

2. Donaldson T, Dunfee TW. Toward a unified conception of business ethics: Integrative social contracts theory. Academy of Management Review. 1994; 19(2):252-84. https://doi. org $/ 10.2307 / 258705$

3. Dudley-Evans T. Five questions for LSP teacher training. Teacher Education for LSP. 1997. p. 58-67.

4. Dudley-Evans Tony, St John MJ. Developments in English for Specific Purposes. Cambridge: CUP. 1998. 
5. Gao X. A content analysis of business English study literature. Journal of Teaching English for Specific and Academic Purposes. 2017; 4(3):465-76.

6. Miralpeix I, Munoz C. Receptive vocabulary size and its relationship to EFL language skills. International Review of
Applied Linguistics in Language Teaching. 2018; 56(1):1-24. https://doi.org/10.1515/iral-2017-0016

7. Olshtain E, Celce-Murcia M. Teaching language skills from a discourse perspective. Handbook of Research in Second Language Teaching and Learning. Routledge. 2016. p. 144-58. https://doi.org/10.4324/9781315716893-11 


\section{Appendix A}

\section{Interview questions}

\section{Questions for the Owner of the Company}

1. What are the company's mission and vision?

2. What are your aims for having EOP classes in your company?

3. What are your facilities and equipment for holding this course?

4. List the value system slogan (motto) of your company?

\section{Appendix B}

\section{Questions for the Trade Manager}

1. What are your expectations and needs from the EOP classes?

2. Please describe the process and steps of import in your company?

3. Which kinds of communicative activities involved in the import section of your company?

4. To what extent your staff needs to use English as a part of the job? What skills do they need more?

5. What are your staffs' difficulties in using language? Mention the problems which they are facing with.

6. What are the weak points of your staff regarding their English levels?

7. In what ways would an EOP course benefit your company?

8. What is the best time to hold the class?
A. In-office hours
B. After office hours

9. Did your staff pass any EOP training courses?

10. Do you use any software (Such as Outlook, Skype) in import section?

11. With whom does your staff communicate with?

\section{Appendix C}

\section{Questionnaire for the import section of the Company (Staff needs analysis)}

\section{Please answer the following questions. Your cooperation is much appreciated.}

Note: You can write your answers in your native language. Your personal information will be kept confidential. Thank you very much.

\section{A. Contact Information}

Full name:

Phone number:

E-mail: 


\section{B. Background}

- What is your gender?
Male
Female
$28-38$
$39-49$
$50-60$

- What is your age?

- Fill in the following table according to your university studies, mention your university degree, major, and also list the ESP courses which you have passed during your university studies.

\begin{tabular}{|l|l|}
\hline University degree & \\
\hline Major & \\
\hline ESP Course(s) & \\
\hline
\end{tabular}

- Major after you left university?

- What are your communicative activities in the import section that you do in English language? List them below and Write the number of years you worked in each area.

\begin{tabular}{|c|l|l|l|l|}
\hline No & \multicolumn{1}{|c|}{ Communicative activities } & Purpose & Participants involved & $\begin{array}{c}\text { Number of Years of } \\
\text { experience }\end{array}$ \\
\hline 1 & Answering phones & & & \\
\hline 2 & Chatting online & & & \\
\hline 3 & Sending and replying emails & & & \\
\hline 4 & Asking for new products, catalogs & & & \\
\hline 5 & Sending inquiries & & & \\
\hline 6 & Writing a business contract & & & \\
\hline 7 & Asking for Proforma Invoice & & & \\
\hline
\end{tabular}

Any other relevant information: Please specify

\section{Language skills}

1. Did you study English before you come to this company? (e.g., In English Institutes)

2. What is your level of English proficiency in the following skills? Please tick accordingly.

\begin{tabular}{|l|l|l|l|l|}
\hline & Beginner & Intermediate & Upper-Intermediate & Advanced \\
\hline Speaking & & & & \\
\hline Writing & & & & \\
\hline Reading & & & & \\
\hline Listening & & & & \\
\hline Grammar & & & \\
\hline
\end{tabular}

\section{Work information}

Why is English important as a part of your job? Please list them below:

1.

2.

3.

\section{E. English improvement goals}

1. If you are given training in the English language, which skills would you like to focus on?

1.

2.

3. 
2. What is your preferred learning style?
A. Group work
B. Role play
C. Case study
D. Presentations and lectures
E. Movie and films
F. Task-based workshop 